\title{
Level of urbanization and habitat type, and not patch size, influence predacious arthropod diversity patterns of urban grasslands in South Africa
}

\author{
BIANCA GREYVENSTEIN ${ }^{1, \bullet}$, MONIQUE BOTHA ${ }^{2}$, JOHNNIE VAN DEN BERG ${ }^{1}$, STEFAN J. SIEBERT ${ }^{1}$ \\ ${ }^{1}$ Unit for Environmental Sciences and Management, North-West University. Private Bag X6001, Potchefstroom 2520, South Africa. \\ Tel. +27836448085, "email: biagrey90@gmail.com \\ ${ }^{2}$ Department of Plant and Soil Sciences, University of Pretoria. Private bag X20, Hatfield 0028, South Africa.
}

Manuscript received: 31 July 2021. Revision accepted: 30 August 2021.

\begin{abstract}
Greyvenstein B, Botha M, van den Berg J, Siebert SJ. 2021. Level of urbanization and habitat type, and not patch size, influence predacious arthropod diversity patterns of urban grasslands in South Africa. Biodiversitas 22: 4078-4094. Predacious arthropods provide a valuable ecosystem service within urban environments by suppressing pest numbers. However, urban ecological studies largely ignore this functional group and its diversity and species composition patterns. Some studies have been published regarding these patterns, however they were mostly done in Australia, Europe and America, thus an African perspective is lacking. Our aim was to address the gap in African literature by quantify the differences in predacious arthropod species richness and diversity within urban green space in varying urbanization intensities, habitat types of grassland and patch sizes in South Africa. Various indices were considered to examine the effect of urbanization on the diversity patterns of Chrysopidae (Neuroptera), Mantodea, Araneae and Coccinellidae (Coleoptera). Study sites included three levels of urbanization represented by population density, two types of urban grasslands (i.e., ruderal and fragmented grassland) and a peri-urban rangeland grassland as control, and a wide range of patch sizes. Our results indicated that an increase in urbanization intensities was associated with increased abundance of predacious arthropod taxa. Also, that urban and peri-urban grasslands had similar predacious arthropod species richness and diversity, but differed in species composition. No relationship was found between patch size and arthropod diversity or composition. Thus, predacious arthropod abundances are influenced by the level of urbanization and their species composition is influenced by the type of urban grassland (ruderal or fragmented), which are important considerations for future urban planning/management and conservation strategies. This study gives a South African perspective and indicates that despite the lack of assigned function of urban green spaces, they sustain diverse and distinct predacious arthropod communities, which in turn fulfil various roles in a functioning ecosystem.
\end{abstract}

Keywords: Conservation, disturbances, green space, predacious, urbanization

\section{INTRODUCTION}

Biodiversity in all its components provides and maintains a variety of ecosystem services (Gardiner et al. 2013; Evers et al. 2018; Kremen and Merenlender 2018; Wani and Sahoo 2021). Complex interactions between abiotic and biotic components in ecosystems determine the quantity, quality and reliability of these services (Mace et al. 2012). In grassy landscapes, the herbaceous layer provides forage and habitat to arthropods (Botha et al. 2017, Janse Van Rensburg et al. 2020). These herbaceous layers can be very diverse and thus provide more habitat and foraging opportunities, especially for predacious arthropods. Predacious arthropods are vital in pest control services in an agricultural setting but also in urban food gardens that are becoming an important food resource for urban populations (Philpott and Bichier 2017). Several factors in urban gardens have been reported to influence predacious arthropods such as vegetation complexity and garden size (Philpott and Bichier 2017). This implies that not only are ecosystem functions dependent on the survival of arthropod species, but the well-being of humanity is affected as well (Alcamo and Bennett 2003).
Biodiversity loss due to land-use intensification has become an issue of concern (Bullock et al. 2011; Marques et al. 2019). When natural areas are transformed to alternative land-uses for direct human and economic benefits, ecosystems are transformed and many species are displaced (Ellis et al. 2012). Negative large-scale effects on specific arthropod groups, e.g. beetles, leafhoppers and true bugs, have been reported where land-use change has resulted in transformed ecosystems (Sanchez-Bayor and Wyckhuys 2019). Recently, a group of scientists warn end global communities about the declines in insect populations and highlighted that land-use change and the associated habitat loss, fragmentation, and degradation are key drivers of these declines (Cardoso et al. 2020).

A review of urban arthropod literature by Faeth et al. (2011) reported that declines in arthropod richness were recorded in $94 \%$ of studies. Decreases in species richness result in lower beta diversity with a subsequent homogenization of biota (Piano et al. 2019), possibly because of dominance of arthropods associated with nonnative plant species (Blouin et al. 2019). Species richness of low mobility species is known to be influenced by city age, impervious area and management, while pollinators, 
high mobility and phytophagous species are mostly influenced by the configuration and composition of the urban spaces (Sattler et al. 2011). According to Faeth et al. (2011), this could be ascribed to plant species composition being actively "managed" by people, and that the arthropods and birds within the city thus follow the plant "template" created by humans in cities.

Although literature is generally in agreement about species richness losses due to urbanization, inconsistencies concerning the effects of urbanization on arthropod composition have been reported. For example, a study on butterflies (Lepidoptera) has shown that the species composition of communities became similar (homogenized) as urban sprawl (expansion or increase of urban areas) occurred (Blair 2001). In contrast, homogenization was not reported for carabid beetles, as their species communities changed due to the effect of urbanization on habitat (Magura et al. 2010). This finding cautions against testing urbanization effects on combined multi-taxa datasets of species richness only, and provides support for analyses of diversity patterns of selected functional groups, such as predacious arthropods, both in terms of diversity and composition (Buschke and Seamann 2011; Botha et al. 2018).

Ecological interactions between arthropod predators and their prey are also affected by urbanization in complex ways. Rocha and Fellowes (2018) found that predaceous arthropod abundance was linked to the size of aphid colonies, but was still negatively affected by an increase in size of urbanized areas, even if the size of aphid colonies remained the same. Corcos et al. (2019) reported that predators and parasitoids are influenced by urbanization at various scales (local, landscape and sub-regional). For example, at a landscape scale, the evenness of predators increased, which could be due to an increase of generalist and mobile species (Jones and Leather 2012; Corcos et al. 2019). In contrast, at a local scale, buildings and streets were reported to act as barriers which resulted in decreasing species abundance, richness and evenness, suggesting that the mobility of predators and prey was affected. Coccinellids are often abundant in urban areas (Egerer et al. 2018a), in some cases are even more than in rural areas, indicating that urban areas have sufficient prey to maintain larger populations of certain predatory species (Gardiner et al. 2013; Honek et al. 2017).

Current understanding of the diversity patterns of predacious arthropods in urban environments, as considered above, predominantly originate from the global North. These findings are regarded as a benchmark and have on occasion been incorporated into management plans of urban green spaces in Africa (Cilliers et al. 2017). However, these trends have never been tested for the continent with its predominantly savannah fauna and flora. Existing African literature has mainly focussed on the process of recovery of arthropod diversity after habitat restoration in urban settings (Whitmore et al. 2002, Pryke and Samways 2009). It is evident that research on arthropod diversity patterns associated with green space in the Southern Hemisphere is limited (Threlfall et al. 2015;
New 2018), with research on grasslands specifically lacking (Buschke and Seamann 2011).

The aim of this study was to determine how certain predatory arthropod groups differ across patch sizes, urbanization intensities, and urban grassland types. We quantified occurrence patterns to address three objectives. Firstly, we determined whether predacious arthropod richness is correlated to the surface area (patch size) of urban green spaces (i.e., fragmented and ruderal grasslands). Secondly, we compared the diversity and community composition of predacious arthropods of these grassland types in three urban settlements that vary in terms of human population density (urbanization intensity). Thirdly, we compared species diversity measures and composition of predacious arthropods between urban and more natural, peri-urban rangeland grasslands.

We hypothesized that there would be a positive correlation between patch size and arthropod species richness as reported by Soga et al. (2013) and Peng et al. (2020). Studies have also indicated that increased human population densities have different effects on different arthropod groups, and we expected to see similar effects in this study (Gardiner et al. 2013; Honek et al. 2017). We predicted that all diversity measures would be highest in fragmented grassland and lowest in most transformed urban green space, i.e. ruderal grasslands, as this was the case in a study conducted by McKinney (2008). In contrast to this, we expected no differences in species assemblages across settlements due to biotic homogenization (Honek et al. 2017). Lastly, we predicted that disturbed urban grasslands would have lower diversity than that of more natural peri-urban rangeland, as urban habitats filter out habitat specialists (McIntyre et al. 2001).

\section{MATERIALS AND METHODS}

\section{Study areas}

Three settlements within the Mesic Highveld Grassland bioregion of South Africa (Botha et al. 2018), i.e., Vanderbijlpark, Potchefstroom and Ventersdorp, were chosen with each represented a different human population density to reflect the level of urbanization (Du Toit and Cilliers 2011). With an increase in population density, an associated increase in the effect of urbanization is probable due to the increase of activities, such as construction of infrastructure for housing, industry, and transport. The city of Vanderbijlpark is associated with the highest population density (HPD) (Figure 1; Table 2), whereas Potchefstroom was considered intermediate (IPD) and Ventersdorp as the lowest (LPD). Within the green space of these settlements, sample sites were chosen from similar types of grassland, namely ruderal and fragmented grasslands within the settlements, and a peri-urban rangeland grassland (as a control).

Each grassland type within the three settlements was defined based on different intensities of disturbance. A disturbance index (Table 1) was developed based on data collected through visual observation and monitoring during the study period. Satellite and terrain images (Google Earth 
2015) were used to determine the proximity of disturbance sources (i.e. industrial parks that would increase pollution of soil and air, buildings, clearings, and agricultural activities that increase pesticide applications and soil disturbance). Since disturbance intensity affects the vegetation of the remnant urban green spaces, disturbance intensity can be seen as a proxy for habitat type.

Ruderal grasslands were defined as green spaces that have been considerably transformed by exogenous disturbance, and have undergone secondary succession after the disturbance events (Cilliers and Bredenkamp 1999). These patches are characterized by high levels of soil disturbance, clearing, refuge dumping, pathways, construction, and mowing (Cilliers and Bredenkamp 1999). Fragmented grasslands were defined as isolated remnant green spaces within settlements that are isolated from other similar fragments by city infrastructure, and are regularly mowed and subjected to air pollution (Cilliers et al. 2008). These grasslands are not utilized and are characterized by the dominant perennial grass Themeda triandra Forssk. (Poaceae), a species that prefers relatively stable areas (Cilliers et al. 2008). Ruderal and fragmented grasslands in each settlement were not subjected to mowing during the year of this study, but such activity did occur erratically in previous years and was an unpredictable event determined by public pressure and available finance.

Peri-urban rangeland grasslands occur on the city's outskirts and were included as a benchmark for comparative purposes. Rangelands have low disturbance intensity, mainly pollution from nearby associated urban and industrial sites (Venter et al. 2012). As rangelands fall within the agricultural hub, these areas are periodically affected by grazing (Botha et al. 2018).

Patch size was determined using satellite images and measurement tools (Google Earth 2015; Table 2). Measurements were taken in square meters to facilitate further analysis of correlations between patch size and arthropod diversity. Patch sizes ranged from the smallest area, approximately $2000 \mathrm{~m}^{2}$ to the largest, approximately $730000 \mathrm{~m}^{2}$. The average size of the ruderal patches between the three settlements was approximately 38851 $\mathrm{m}^{2}$ while the average fragmented grassland patches between the three settlements were approximately 82177 $\mathrm{m}^{2}$.

Table 1. Overall frequency of disturbance scores for green spaces $(0$ - never; 1 - sometimes; 2 - often; and 3 - very often $)$

\begin{tabular}{lccc}
\hline Disturbance & $\begin{array}{c}\text { Ruderal } \\
\text { grassland }\end{array}$ & $\begin{array}{c}\text { Fragmented } \\
\text { grassland }\end{array}$ & $\begin{array}{c}\text { Peri-urban } \\
\text { rangeland }\end{array}$ \\
\hline Grazing & 0 & 1 & 3 \\
Fire & 2 & 3 & 1 \\
Mowing & 2 & 3 & 1 \\
Dumping & 3 & 1 & 0 \\
Pesticides & 0 & 0 & 1 \\
Air pollution & 3 & 3 & 1 \\
Soil & 3 & 1 & 0 \\
Footpaths & 2 & 3 & 1 \\
Clearing & 3 & 1 & 0 \\
Buildings & 2 & 0 & 0 \\
Total & 20 & 16 & 8 \\
\hline
\end{tabular}

Table 2. GPS coordinates, street names and patch sizes of all sample sites in Vanderbijlpark Potchefstroom and Ventersdorp. Rangeland sites were located outside these cities at -26.472, 26.926; -26.470, 26.932; and -26.466, 26.929.

\begin{tabular}{|c|c|c|c|c|c|}
\hline \multicolumn{3}{|c|}{ Ruderal } & \multicolumn{3}{|c|}{ Fragmented } \\
\hline Coordinates & Street names & Patch size $\left(\mathbf{m}^{2}\right)$ & Coordinates & Street names & Patch size $\left(\mathbf{m}^{2}\right)$ \\
\hline \multicolumn{6}{|c|}{ HPD - Vanderbijlpark (population: 540/km²) } \\
\hline$-26.727,27.872$ & Hendrick van Eck & 44903 & $-26.738,27.855$ & Louis Trichard & 87408 \\
\hline$-26.680,27.815$ & Hans Merensky & 42923 & $-26.699,27.851$ & Wolmarans & 38659 \\
\hline$-26.720,27.816$ & William Nicol & 33543 & $-26.726,27.857$ & Andrew Young & 24577 \\
\hline$-26.701,27.855$ & Wolmarans & 27118 & $-26.673,27.813$ & Delfos & 94058 \\
\hline$-26.672,27.835$ & Delfos & 369960 & $-26.721,27.863$ & Andries Potgieter & 733253 \\
\hline$-26.731,27.859$ & Oranje River & 16903 & $-26.721,27.855$ & Japie Greyling & 80277 \\
\hline$-26.723,27.817$ & Vaal drive & 10543 & $-26.735,27.842$ & Frikkie Meyer & 46187 \\
\hline \multicolumn{6}{|c|}{ IPD- Potchefstroom (population: $270 / \mathrm{km}^{2}$ ) } \\
\hline$-26.696,27.079$ & Rissik & 10730 & $-26.673,27.110$ & MC Roode & 17856 \\
\hline$-26.704,27.080$ & Fontein & 60907 & $-26.745,27.094$ & Viljoen & 7022 \\
\hline$-26.722,27.124$ & Wynne & 10302 & $-26.732,27.093$ & Louw & 15604 \\
\hline$-26.717,27.120$ & Steyn & 33353 & $-26.679,27.115$ & MC Roode & 87849 \\
\hline$-26.690,27.071$ & Deppe & 43556 & $-26.697,27.103$ & Langenhoven & 24986 \\
\hline$-26.736,27.096$ & Eland & 37372 & $-26.673,27.077$ & Tiger-moth & 55888 \\
\hline$-26.692,27.070$ & Russel & 4666 & $-26.662,27.120$ & Dagbreek & 123919 \\
\hline \multicolumn{6}{|c|}{ LPD - Ventersdorp (population: 78/ $\mathbf{k m}^{2}$ ) } \\
\hline$-26.314,26.826$ & Cheyne & 3078 & $-26.307,26.817$ & Eland & 38287 \\
\hline$-26.313,26.826$ & Roth \& Paarl & 2160 & $-26.307,26.825$ & $\mathrm{R} 30$ & 6017 \\
\hline$-26.320,26.820$ & Berg & 2563 & $-26.304,26.827$ & $\mathrm{R} 53$ & 16926 \\
\hline$-26.311,26.816$ & Mark & 17062 & $-26.309,26.818$ & Steenbok & 16508 \\
\hline$-26.313,26.821$ & Cochrane & 5048 & $-26.308,26.814$ & Eland & 135988 \\
\hline$-26.320,26.826$ & Koekemoer & 33536 & $-26.316,26.820$ & Mark & 60185 \\
\hline$-26.311,26.822$ & Anemay \& Visser & 5638 & $-26.319,26.819$ & Berg \& Grey & 14257 \\
\hline
\end{tabular}




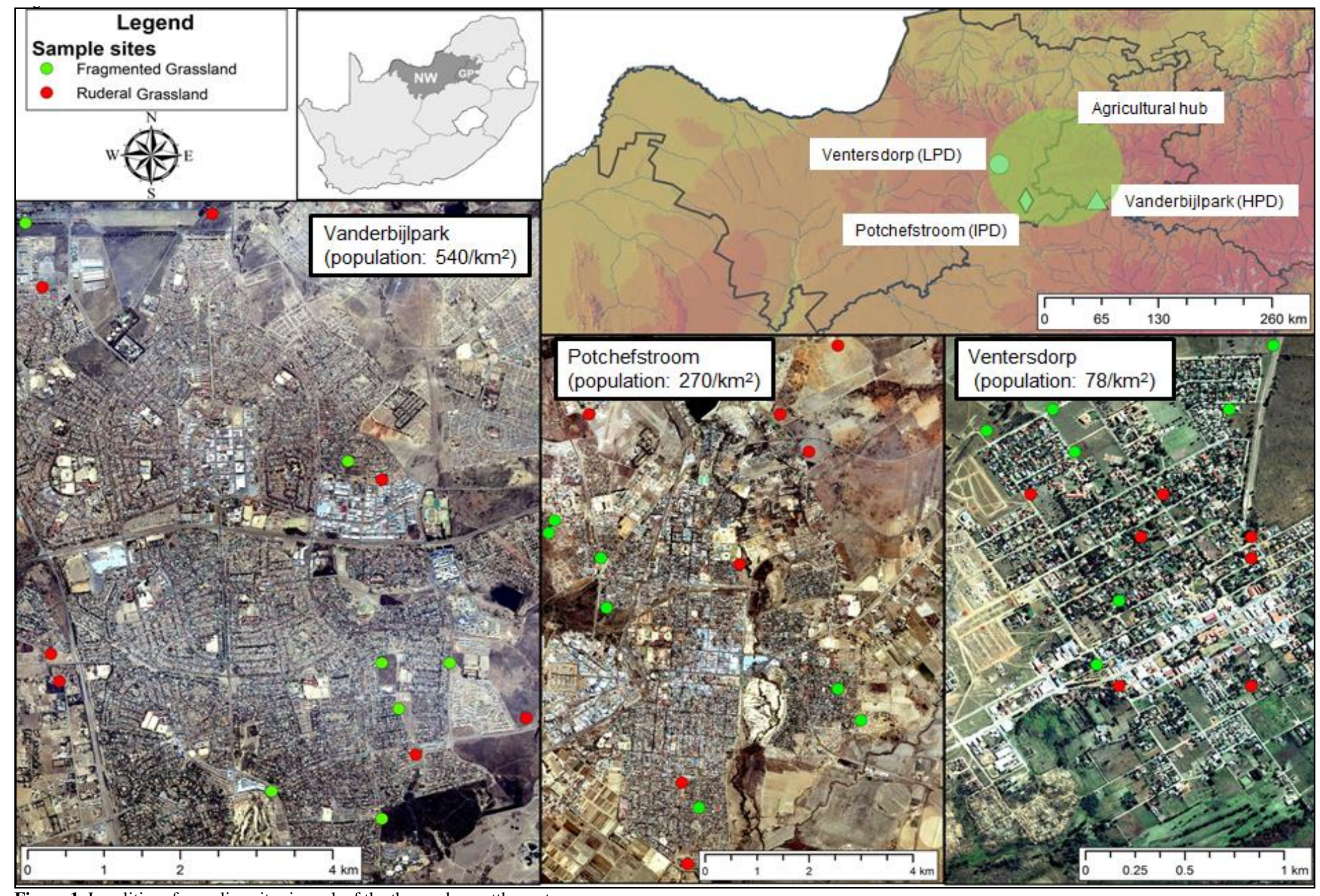

Figure 1. Localities of sampling sites in each of the three urban settlements 


\section{Arthropod sampling}

Each urban settlement (i.e. HPD, IPD and LPD) contained seven survey sites for each of the ruderal and fragmented grasslands. Three replicate samples were taken at each of the seven survey sites per grassland type during summer (the Highveld has unfavorable below-freezing temperatures during winter). This was repeated twice (January and March) during 2015, which is the middle of summer in South Africa and thus an active time for arthropods. A total of 252 samples were collected during this study ( 3 settlements $\times 2$ grassland types $x 7$ survey sites $\times 3$ replicates $\times 2$ repeats). Additionally, three replicates were also taken twice in summer from four periurban rangeland grassland sites (control), resulting in a total of 96 samples ( 3 settlements x 4 control sites x 4 replicates $\mathrm{x} 2$ repeats).

We specifically focussed on spiders (Araneae), ladybirds (Coccinellidae), lacewings (Neuroptera) and praying mantids (Mantodea) in this study. These arthropod groups were chosen since they represent an important functional group in most terrestrial grassland ecosystems (Botha et al. 2018). These predators differ in their level of mobility, i.e. spiders are flightless, mantids are slowmoving ambush predators with limited flight capabilities, while lacewings and coccinellids are good fliers. A combination of these arthropod groups provides a wellrounded picture of grassland arthropod predators in urban versus peri-urban areas.

Arthropods were collected by means of sweep netting. Survey site selection was done based on a sufficient patch area (a minimum of $250 \times 150 \mathrm{~m}$ ) to facilitate sampling of four replicates. Each sample plot was $100 \mathrm{~m}^{2}$ with a minimum of $50 \mathrm{~m}$ between adjacent plots. Each plot was demarcated (care was taken to avoid trampling within the block), and sampled systematically by sweeping from side to side (approximately 30 sweeps per plot). The arthropods collected per plot were placed into marked bags, placed in a cooler bag, then stored in a freezer for later identification. Since sampling was conducted between 08:00 and 14:00, it was assumed that time of day did not influence the abundances of the selected predacious arthropod groups (Greyvenstein et al. 2020b).

Each frozen sample was sorted in $70 \%$ ethanol to separate the lacewings, praying mantids, coccinellids, and spiders. Specimens were identified to species level, except for 154 spiderlings and 155 praying mantids, which could be identified to genus only. Arthropod identification was conducted at the Biosystematics Division, Agricultural Research Council, Pretoria, Gauteng, South Africa. Species were identified with keys for coccinellids (Seago et al. 2011), lacewings (Brooks 1994; Mansell 1997), and spiders (Dippenaar-Schoeman and Jocqué 1997). Praying mantids were identified to genus level using keys by Bragg (19962007) and Kaltenbach (1996, 1998), and a reference collection at the Ditsong Museum of Natural History, Pretoria, South Africa. Voucher specimens are housed at the North-West University, Potchefstroom, South Africa.

\section{Data analyses}

Species diversity was quantified using Shannon diversity, species richness and abundance, which was calculated with Primer 6 (Clarke and Gorley 2006). Spearman rank-order correlation coefficients were calculated to determine whether correlations existed between abundance, richness or diversity of predacious arthropods per plot and patch sizes in each settlement (SPSS; IBM 2017). Rarefaction curves were constructed by using overall species richness to determine all species actually discovered (Sobs), Chao's estimator based on number of rare species (chao1), Chao's estimator using just presence-absence data (chao2) and a Boot-strap estimator based on proportion of quadrats containing each species (Botha et al. 2018) (Supplementary Figure S1).

Hierarchical Linear Modelling (HLM) was applied using two-way ANOVA with random effects (McMahon and Diez 2007) in SPSS to test for overall significant differences. Two separate models were fitted to the dataset. The first model tested whether index values (taken as response variables) could be predicted by population size of urban areas (urbanization density). The second model tested if index values could be predicted by the type of grassland (ruderal vs fragmented vs rangeland). In both models, there was no dependency specified and site was included as a random and not paired variable, with the data nested per settlement in the analyses.

Effect sizes (Cohen's d) and pairwise comparisons were calculated to express practical significance between urban population sizes and type of green space. Here residual variance, as well as site variance, were taken into account in the calculation of the effect size of each grassland type and diversity indices (Ellis and Steyn 2003). The effect sizes were interpreted as large if $\mathrm{d}>0.8$ (included as Supplementary Tables B and C).

Differences in species composition between settlements of different population size and between grassland types were visualized with non-metric multidimensional scaling (NMDS) and Bray Curtis dissimilarity in Primer 6. Similarity Percentages (SIMPER) were performed in PAST (Version 2.15; Hammer et al. 2001) to identify the species responsible for grouping within NMDS graphs (included as Tables S4 and S5). Permutational Multivariate ANOVA (PERMANOVA) were performed in Primer 6 to test for significant differences in predator species composition between urban settlements and between grassland types (urban settlement and grassland types as fixed effects; sample sites as random effects).

\section{RESULTS AND DISCUSSION}

\section{Arthropod diversity}

Urban (ruderal and fragmented) grasslands contained 30 spider $(\mathrm{N}=830)$, seven coccinellid $(\mathrm{N}=391)$, seven praying mantid $(\mathrm{N}=74)$ and two lacewing $(\mathrm{N}=26)$ species. Peri-urban rangeland grasslands yielded 36 spider $(\mathrm{N}=564)$, seven coccinellid $(\mathrm{N}=417)$, eight mantid $(\mathrm{N}=$ $336)$ and two lacewing $(\mathrm{N}=232)$ species (Figure 2). Since only two lacewing species were collected overall, only 
abundances of this group could be included in further analyses. A list of predacious arthropod species names and occurrences is provided in Table $\mathrm{S} 1$.

\section{Correlation between patch size and predator diversity}

No significant correlations were found between patch size and predator richness and Shannon diversity, neither for the entire urban environment, nor for the separate ruderal and fragmented grassland sites (Table 3). This indicated that patch size had no effect on the richness or diversity of predacious arthropods. However, a significant positive $(\mathrm{r}=0.596, \mathrm{P}=0.004)$ correlation was recorded between overall arthropod abundance per plot and patch size in the ruderal grasslands. This is probably an artifact created by the significant positive correlation $(\mathrm{r}=0.51, \mathrm{P}=$ 0.018 ) between patch size and abundance (total number of individuals per plot) for coccinellids. Since this result was considered an outlier and there was a poor correlation $(\mathrm{r}<$ 0.6 ), results were further on considered as independent of patch size.

\section{Comparisons of arthropods between urban settlements (effect of human population density on urban grasslands) Biodiversity}

Pairwise comparisons (Table 4) revealed significant differences in predator abundance for ruderal grasslands, with HPD having higher values than IPD $(d=1.190)$ and LPD ( $\mathrm{d}=1.521)$ (Figures 3 and 4$)$. The fragmented grassland showed significant differences for species richness with HDP having higher values than both IPD ( $\mathrm{d}=$ 1.049) and LPD ( $d=1.077)$. It can therefore be assumed that more densely populated settlements have higher richness and abundance, but not diversity, in ruderal and fragmented grasslands respectively (Table S2).

\section{Species composition}

Ordinations of the arthropod species composition for the ruderal grassland did not reveal clear groupings for the three urban settlements (Figure 5), despite the composition being significantly different between HPD and both LPD $(P=0.001)$ and IPD $(P=0.001)$. The ordinations of arthropod species composition of fragmented grassland across urban settlements showed that the LPD sites formed a separate cluster from the sites of HPD $(\mathrm{P}=0.002)$ and IPD $(\mathrm{P}=0.01)$ (Figure 5.B; Table 5). From this, it seems that more densely populated settlements share the most species in fragmented grasslands, but in the case of ruderal grassland, species assemblages in less densely populated settlements are more similar.

The dissimilarity in arthropod assemblages of settlements were mainly a result of the spider species, $T$. hollidayi and $M$. rubrodecoratus, and the coccinellid, $C$. lunata (Table S4). These species contributed to $>30 \%$ of the overall dissimilarity, with $T$. hollidayi being prominent in HPD and IPD and the second type of IPD and LPD (Table S1). Coccinellids were predominantly associated with HPD.

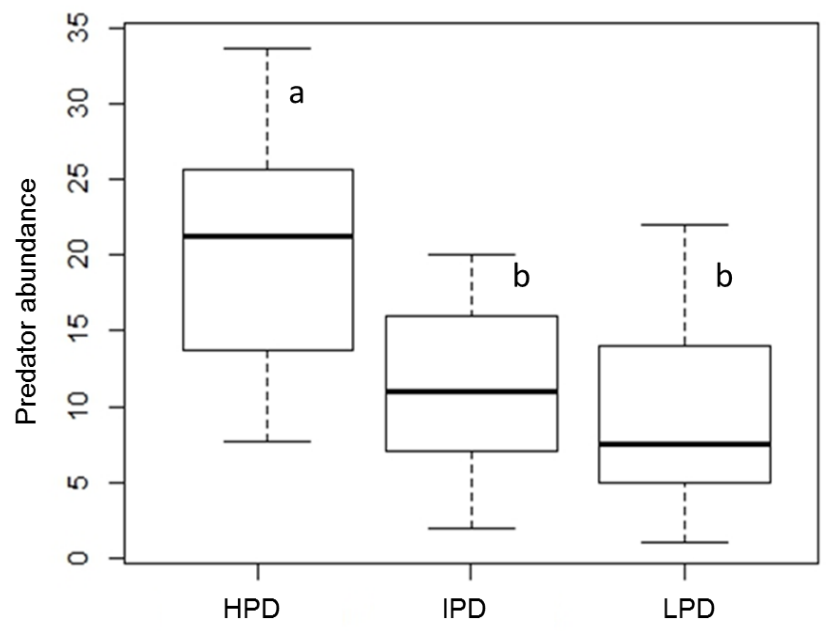

Urban settlements

Figure 3. Overall green space predator abundance between the three urban settlements. Significant differences $(d<0.8)$ were indicated by differing letters ( $a$ and $b$ )
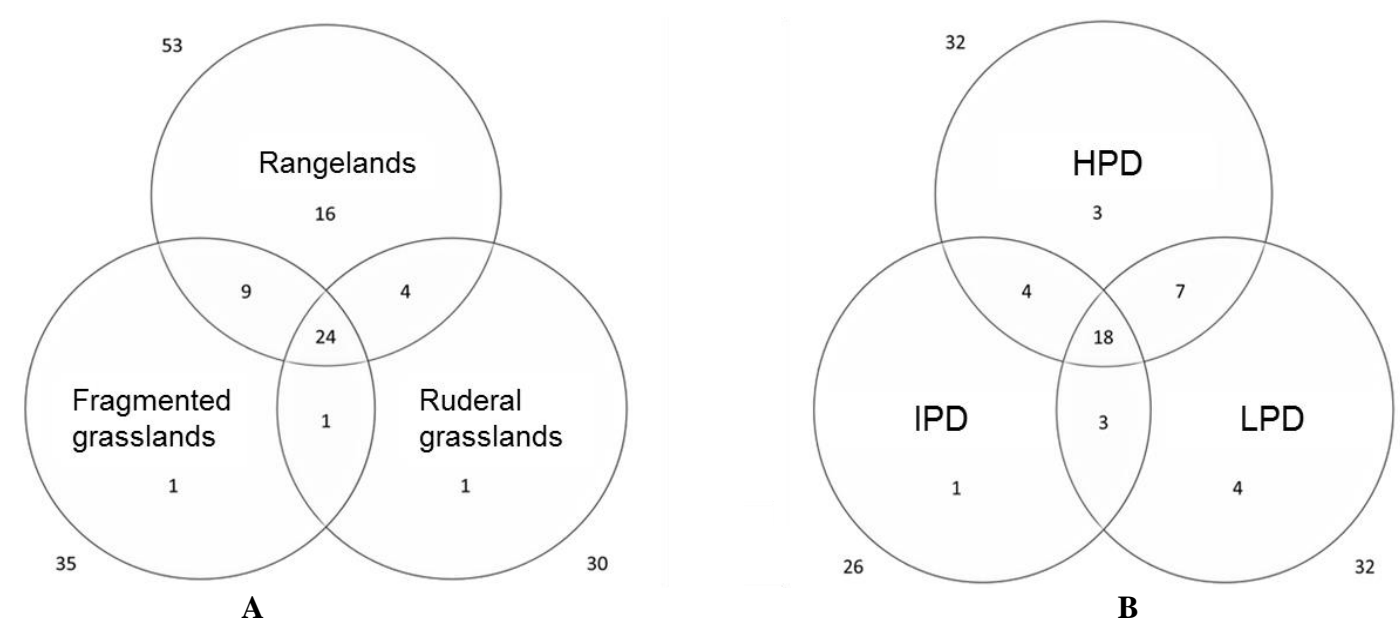

Figure 2. A. Number of unique species in each grassland type and the shared unique species. Total number of species recorded in each grassland type is displayed outside the circle. B. Number of unique species in each urban settlement and the shared unique species. Total number of species recorded in each settlement is displayed outside the circle 
Ruderal

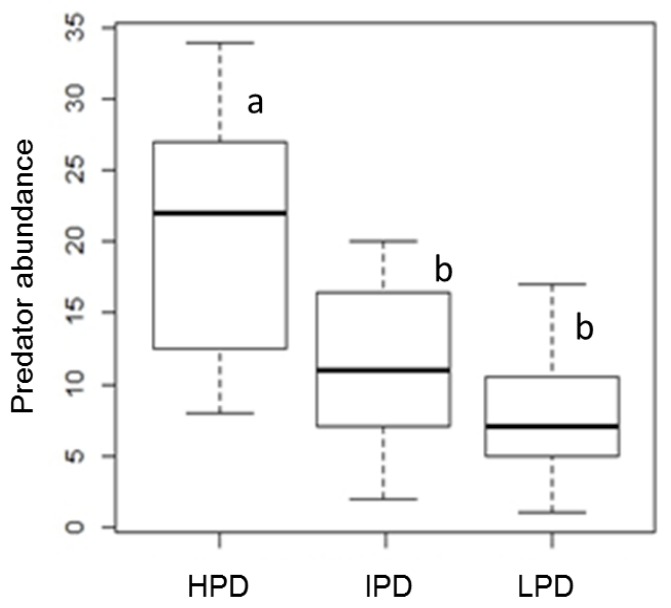

A
Fragmented grassland

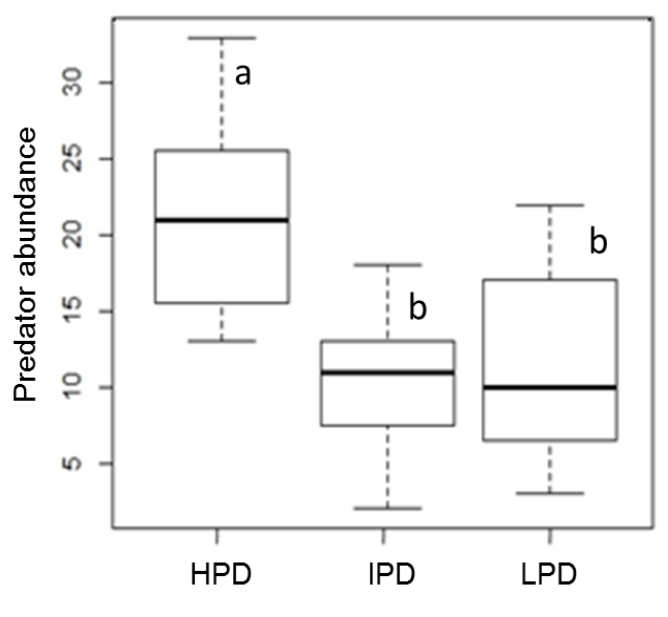

B

Figure 4. Predator abundance of ruderal (A) and fragmented (B) grasslands in three urban settlements. Significant differences (i.e. practical significance $=\mathrm{d}<0.8$ ) indicated by different letters $(a$ and $b$ )

Table 3. Correlation coefficients between patch size and diversity measures of fragmented and ruderal grasslands. * Significant correlation $(r>0.5)$. Overall includes fragment and ruderal grassland data

\begin{tabular}{|c|c|c|c|c|c|}
\hline Diversity indices & $\begin{array}{c}\text { Overall predator } \\
\text { diversity }\end{array}$ & Spiders & Lacewings & Praying mantids & Ladybirds \\
\hline \multicolumn{6}{|l|}{ Overall urban environment } \\
\hline Species Richness per sample plot & 0.262 & 0.240 & $\mathrm{n} / \mathrm{a}$ & 0.315 & -0.110 \\
\hline Total Individuals per sample plot & 0.379 & 0.314 & -0.083 & 0.268 & -0.053 \\
\hline Shannon-Wiener Diversity Index & 0.080 & 0.147 & $\mathrm{n} / \mathrm{a}$ & 0.051 & -0.103 \\
\hline \multicolumn{6}{|l|}{ Fragmented grasslands } \\
\hline Species Richness per sample plot & 0.020 & -0.036 & $\mathrm{n} / \mathrm{a}$ & 0.315 & -0.256 \\
\hline Total Individuals per sample plot & 0.150 & 0.111 & -0.195 & 0.268 & -0.173 \\
\hline Shannon-Wiener Diversity Index & -0.099 & 0.058 & $\mathrm{n} / \mathrm{a}$ & 0.051 & -0.269 \\
\hline \multicolumn{6}{|l|}{ Ruderal grasslands } \\
\hline Species Richness per sample plot & 0.415 & 0.283 & $\mathrm{n} / \mathrm{a}$ & 0.232 & 0.289 \\
\hline Total Individuals per sample plot & $0.596^{*}$ & 0.234 & 0.040 & 0.207 & $0.510^{*}$ \\
\hline Shannon-Wiener Diversity Index & 0.273 & 0.172 & $\mathrm{n} / \mathrm{a}$ & 0.046 & 0.248 \\
\hline
\end{tabular}

Table 4. Results for Hierarchical linear modeling (HLM) indicating overall differences in predator diversity index values between urban settlements.

\begin{tabular}{|c|c|c|c|c|c|}
\hline & & & Species richness & Abundance & Shannon-Wiener index \\
\hline \multirow[t]{7}{*}{ Ruderal grassland } & \multirow[t]{2}{*}{ Urban settlement } & F-value & 2.918 & 8.766 & 0.82 \\
\hline & & p-value & 0.093 & $0.005^{*}$ & 0.463 \\
\hline & \multirow[t]{2}{*}{ MSE Variance } & & 3.178 & 85.378 & 0.183 \\
\hline & & & 0.619 & 4.256 & 0.023 \\
\hline & \multirow{3}{*}{ Pairwise comparisons } & HPD & $6.53 b$ & $22.867 b$ & 1.532 \\
\hline & & IPD & $5.20 \mathrm{a}$ & $11.600 \mathrm{a}$ & 1.390 \\
\hline & & LPD & $4.60 \mathrm{a}$ & $8.467 \mathrm{a}$ & 1.299 \\
\hline \multirow[t]{7}{*}{ Fragmented grassland } & \multirow[t]{2}{*}{ Urban settlement } & F-value & 3.698 & 2.686 & 2.648 \\
\hline & & p-value & 0.056 & 0.109 & 0.111 \\
\hline & \multirow[t]{2}{*}{ MSE Variance } & & 4.067 & 26.511 & 0.225 \\
\hline & & & 1.463 & 41.411 & 0.028 \\
\hline & \multirow[t]{3}{*}{ Pairwise comparisons } & HPD & $7.667 b$ & $21.267 \mathrm{~b}$ & $1.675 \mathrm{a}$ \\
\hline & & IPD & $5.200 \mathrm{a}$ & $13.133 \mathrm{a}$ & $1.271 \mathrm{~b}$ \\
\hline & & LPD & $5.133 \mathrm{a}$ & $11.600 \mathrm{a}$ & $1.271 \mathrm{a}$ \\
\hline
\end{tabular}

Note: HPD: Vanderbijlpark; IPD: Potchefstroom; LPD: Ventersdorp, * indicates significant $p$ values at $p \leq 0.05$. MSE $=$ mean square error unexplained variance. Variance: variance explained by predictor variable. Pairwise comparisons significant differences (i.e. practical significance $=\mathrm{d}<0.8$ ) indicated by different letters $(a$ and $b)$. 


\section{Comparisons of arthropods between urban green} spaces (ruderal, fragmented and peri-urban grasslands) Biodiversity

Species richness, abundance, and Shannon-Wiener diversity indices were all significantly different among the three grassland types (Figure 6; Table 6). Large effect sizes $(\mathrm{d}>0.8)$ were recorded between the ruderal/fragmented grasslands and rangeland grasslands, as the latter had significantly higher values. This implies that urban grasslands have similar predator diversity, but this diversity was significantly lower than that of peri-urban rangeland grasslands (Table S3).

\section{Species composition}

Ordinations indicated that the rangeland grassland predator assemblages differed from that of the urban fragmented and ruderal grasslands (PERMANOVA P = 0.001 for all pairwise comparisons) (Figure 7; Table 7) However, a tightly overlapping clustering was observed for predacious arthropod assemblages of ruderal and fragmented grasslands.

Despite this clustering, a significant difference was recorded (PERMANOVA $\mathrm{P}=0.001$ ) between the two, suggesting dissimilarity. It can be deduced that urban green spaces (ruderal and fragmented grasslands) and peri-urban rangeland differ in terms of their predacious arthropod species assemblages (Figure 7; Table 7).

The dissimilarity in arthropod assemblages of grassland types was also mainly a result of the spider species, $T$. hollidayi and M. rubrodecoratus, and the coccinellid, $C$. lunata (Table S5). These species contributed to $>30 \%$ of the overall dissimilarity. T. hollidayi and $C$. lunata were prominent in rangeland grasslands and $M$. rubrodecoratus was typical of fragmented grassland (Table S1).

Table 7. Permutational multivariate analysis of variance (PERMANOVA) results indicating differences in predator species composition between three green spaces

\begin{tabular}{llll}
\hline $\begin{array}{l}\text { Overall } \\
\text { effect }\end{array}$ & & $\begin{array}{l}\text { Pseudo-F } \\
\text { p-value }\end{array}$ & $\begin{array}{l}\mathbf{1 1 . 2 6 1} \\
\mathbf{0 . 0 0 1}\end{array}$ \\
\hline Pairwise & Ruderal x Fragmented & t-value & 2.5739 \\
& grassland & p-value & $0.001^{*}$ \\
& Ruderal x Peri-urban & t-value & 3.0886 \\
& rangeland & p-value & $0.001^{*}$ \\
& Fragmented grassland x & t-value & 4.2186 \\
& Peri-urban rangeland & p-value & $0.001^{*}$ \\
\hline
\end{tabular}

Note: $\mathrm{t}: \mathrm{t}$ value; $\mathrm{p}: \mathrm{p}$ value. Permutations $=999 ;$ Bray-Curtis similarity; ${ }^{*} \mathrm{p} \leq 0.05$

Table 5. Permutational multivariate analysis of variance (PERMANOVA) results indicating differences in predator species composition between green spaces of three urban settlements

\begin{tabular}{lcccc}
\hline & & Ruderal grassland & Fragmented grassland \\
\hline Overall effect & & Pseudo-F & 2.1241 & 4.7791 \\
Pairwise & p & $\mathrm{p}$ & $0.005^{*}$ & $0.001^{*}$ \\
& & $\mathrm{t}$ & 1.6234 & 2.662 \\
& HPD x LPD & $\mathrm{p}$ & $0.002^{*}$ & $0.001^{*}$ \\
& & $\mathrm{t}$ & 1.6148 & 1.2369 \\
& LPD x IPD & $\mathrm{p}$ & $0.01^{*}$ & 0.157 \\
& & $\mathrm{t}$ & 1.1309 & 2.3636 \\
& & $\mathrm{p}$ & 0.265 & $0.001^{*}$ \\
\hline
\end{tabular}

Note: HPD: Vanderbijlpark; IPD: Potchefstroom; LPD: Ventersdorp. t: $t$ value; $p$ : $p$ value. Permutations = 999; Bray-Curtis similarity; ${ }^{*} \mathrm{p} \leq 0.05$

Table 6. Results for Hierarchical linear modeling (HLM) indicating overall differences in predator diversity index values between three green space types.

\begin{tabular}{|c|c|c|c|c|}
\hline & & Species richness & Abundance & Shannon-Wiener index \\
\hline \multirow[t]{2}{*}{ Urbanisation } & F-value & 13.501 & 11.584 & 7.086 \\
\hline & p-value & $<0.001 *$ & $<0.001 *$ & $0.002 *$ \\
\hline MSE & & 6.489 & 186.748 & 0.204 \\
\hline Variance & & 4.284 & 103.904 & 0.059 \\
\hline \multirow{3}{*}{ Pairwise comparisons } & Ruderal grassland & $5.444 \mathrm{a}$ & $14.311 \mathrm{a}$ & $1.407 \mathrm{a}$ \\
\hline & Fragmented grassland & $6.000 \mathrm{a}$ & $15.333 \mathrm{a}$ & $1.406 \mathrm{a}$ \\
\hline & Peri-urban rangeland & $9.867 \mathrm{~b}$ & $34.422 b$ & $1.830 \mathrm{~b}$ \\
\hline
\end{tabular}

Note: F: F value; $p$ : p-value. * indicates significant $p$ values at $p \leq 0.05 . \mathrm{MSE}=$ mean square error unexplained variance. Variance: variance explained by predictor variable. Pairwise comparisons significant differences (i.e. practical significance $=\mathrm{d}<0.8)$ indicated by different letters ( $a$ and $b)$ 


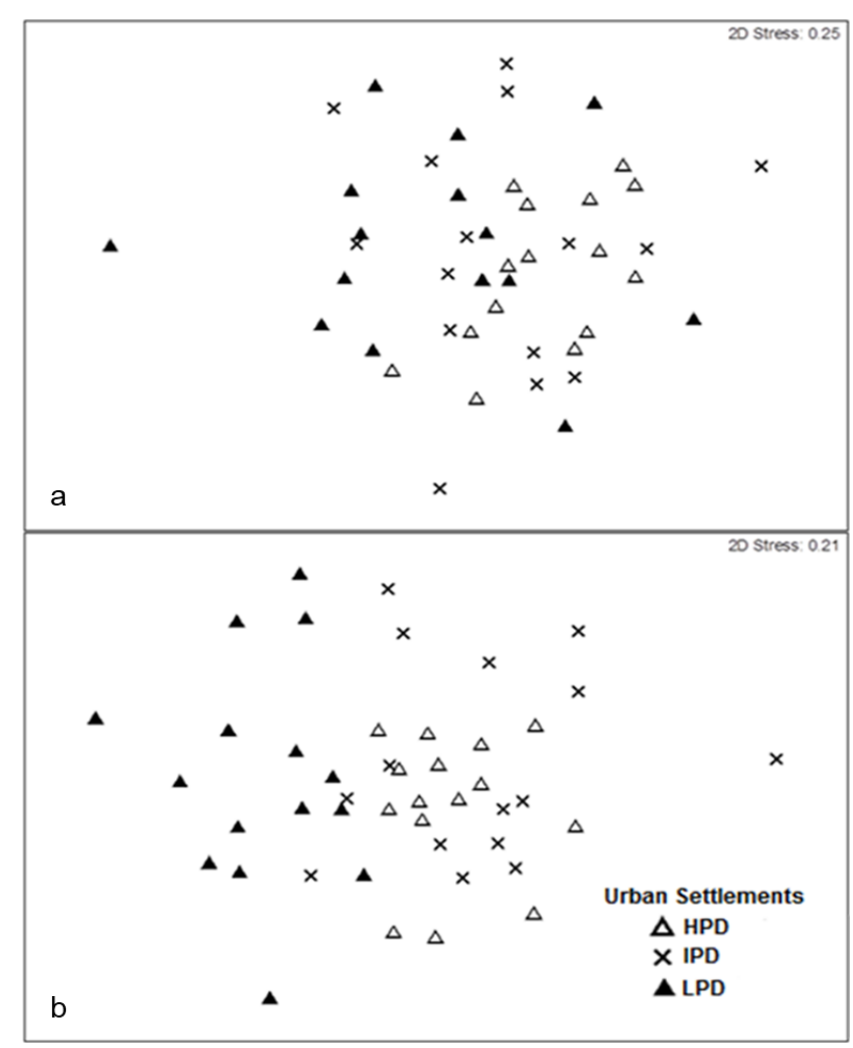

Figure 5. Non-metric multidimensional scaling (NMDS) ordination indicating differences in predator species composition between urban settlements for ruderal (A) and fragmented grasslands (B)

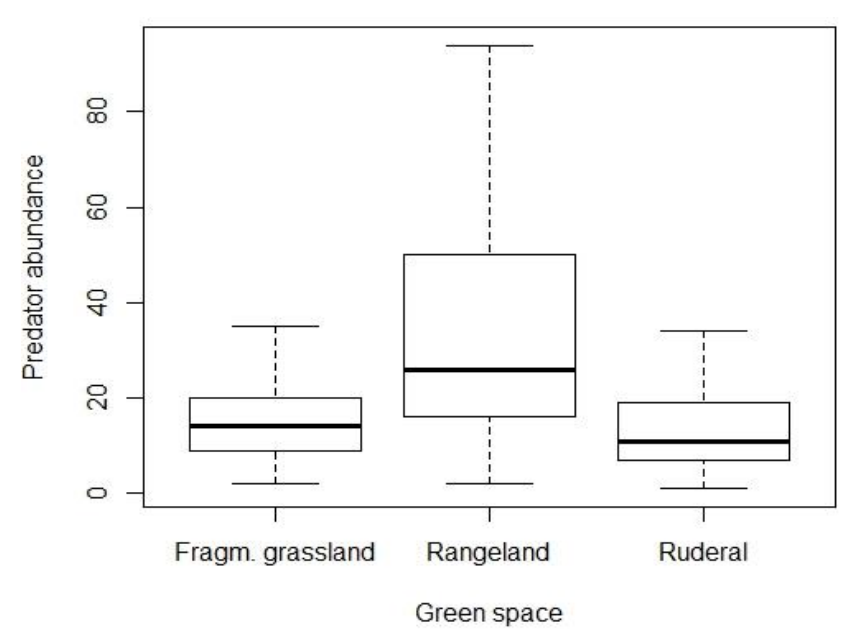

Figure 6. Overall predator abundance in three green space types

\section{Discussion}

Most of the studies done in urban ecology were done in North and South America, Europe, and Australia which creates a bias in the literature (Dale and Frank 2018). This study attempts to contribute to the gap in literature and add to the few studies that have been done on arthropods of urban environments on the African continent. Many of the existing studies were conducted on urban grassland vegetation (Cilliers and Bredenkamp 1999; Cilliers et al. 2008). Therefore, this study is novel for the region and generates baseline data about predacious arthropods in South African urban settlements.

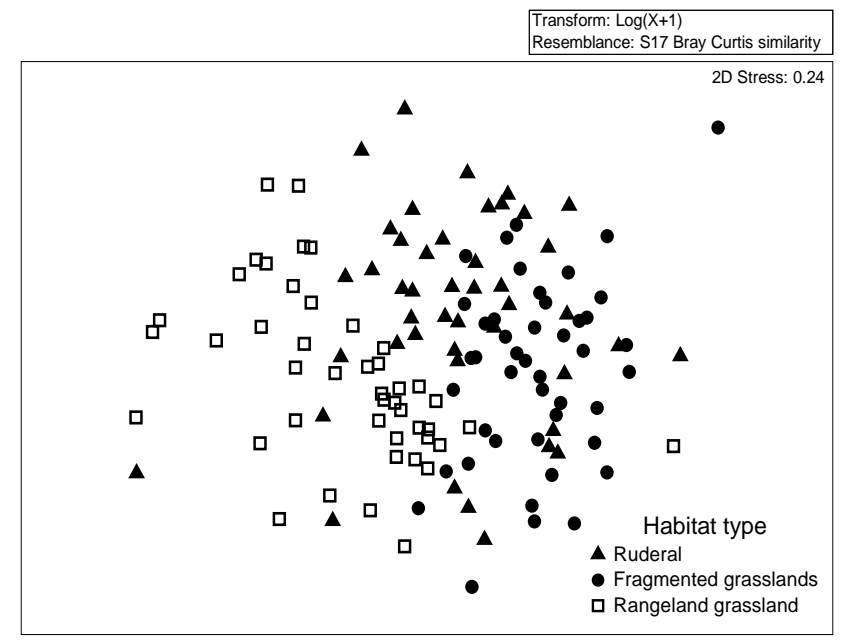

Figure 7. Non-metric multidimensional scaling (NMDS) ordination indicating differences in predator species composition between three green space types.

The first objective of the study was to determine whether the abundance, species richness and diversity of predacious arthropods were positively correlated to the patch sizes of urban green space. Results suggest that larger patches do not result in higher diversity and abundance of predators in urban grasslands. Gibbs and Hochuli (2002) also reported that smaller patches did not have lower species richness per sampling unit in Australia, but that it resulted in different species assemblages. Gibbs and Hochuli (2002) suggested that arthropods were influenced more by the decreasing quality of the habitat due to urbanization, rather than patch size, especially arthropods of higher trophic levels. Findings presented here corroborate this, as predacious arthropod diversity was not correlated with patch size, but quality of habitat as will be discussed later. Furthermore, isolation of patches has also been reported to influence arthropods more than patch size (Burkman et al. 2014; Delgado de la flor et al. 2019).

However, a positive correlation was recorded for coccinellid abundance and increasing patch size in ruderal grasslands, which did not apply to any of the other predacious arthropods. Rocha and Fellowes (2018) found that impervious surfaces did not influence coccinellid abundance but that prey (aphid) abundance and plant species richness were more important. Aphid abundance in urban areas of central Argentina was also reported to increase with an increase in the level of urbanization (Wagner et al. 2017). The positive correlation between coccinellid abundance observed in our study could therefore also be linked to the higher urbanization levels in HPD, which could have influenced the abundance of aphids (originating from nearby garden floras), and subsequently, coccinellids. Furthermore, Egerer et al. (2018b) reported that higher coccinellid abundance and richness was maintained in garden within low-quality cityscapes i.e. areas with more impervious surfaces, thus suggesting that higher levels of urbanization as encountered in HPD would not affect this predatory arthropod group. 
The second objective of this study, to test if abundance, richness and diversity of predacious arthropods decrease as urbanization (human density) increases, indicating that the largest city (HPD) had the highest abundance and richness for the ruderal and fragmented grasslands, respectively and no differences in Shannon-Wiener diversity were recorded. These results are supported by Kozlov et al. (2017), reporting that as the size of a European city increased, the survival rates of leafminers decreased due to increased predation. This suggests that predators are influenced to a lesser extent by the mere presence of anthropogenic attributes of urbanization, i.e. buildings, roads and scattered green space, but are rather influenced strongly by other biotic factors that enhance prey numbers and host plant quality in urban ecosystems. Wagner et al. (2017) indicated that aphids increase in abundance as the level of urbanization increases, which could explain the higher abundances of the selected predaceous arthropods found for HPD in our study.

Aphids are a common source of prey for various predators, but especially for the larval stages of coccinellids, neuropterans and mantids. Of all the species of mantids collected in this study, Galepsus spp. were the most common in the urban areas. Early nymphal stages of these species in particular feed on aphids as this food resource is abundant and appropriate in size for these nymphs (Greyvenstein et al. 2020a). Thus large aphid colonies associated with higher levels of disturbance could sustain more predacious arthropods, especially in their associated nymphal stages. This indicates the importance of biotic factors within urban environments and as reported by Turrini et al. (2016) species interactions are an important aspect of any ecosystem and were shown to be affected by direct and indirect interactions because of top-down forces in Swiss urban environments (Turrini et al. 2016).

Ordinations of arthropod assemblages should be approached with caution when making general deductions regarding the observed patterns, because it only presents a snapshot of each community's composition in time since most arthropods are mobile. Nonetheless, our findings did not support biotic homogenization for predacious arthropods across the settlements we examined. Fine scale changes in habitat aspects such as vegetation cover and complexity has been reported to affect the community composition of spiders in Sydney, Australia (Lowe et al. 2017). At a broader scale, Rocha and Fellowes (2020) suggested that specialist predator species are affected by the proportion of green areas in urban environments while generalist species do not follow this pattern, these type of filtering effects within urban environments could contribute to the differences observed in the community compositions of this study. McKinney (2008) indicated that various taxa react differently within urban areas and thus contrasting results are quite prevalent, especially for lower invertebrates such as arthropods.

When urban ruderal and fragmented grasslands are viewed separately, however, homogenization of predaceous arthropod species assemblages in fragmented grassland was observed between more densely populated settlements (HPD and IPD) and in more disturbed, ruderal grasslands homogenization was stronger for less densely populated areas (IPD and LPD). This addresses the second objective of this study which tested for homogenization, and indicates that the process is dependent on the level of urbanization and grassland type. This finding cautions once again to consider scale when interpreting homogenization patterns (McKinney 2008). Similarity percentages indicated that spider species and a few coccinellid species were mostly responsible for the dissimilarity between the settlements, thus not all predacious arthropods influenced the results similarly. In contrast to the results of this study, Fenoglio et al. (2020) reported that the effect of urbanization was similar in all cities despite the size of the city.

Beyond disturbance intensity, Buchholz et al. (2018) indicated that habitat management and isolation (not plant diversity) had a significant influence on carabid and spider species composition in Germany. Isolated sites had lower species richness, whereas irregularly managed sites had higher species richness than extensively managed sites (Buchholz et al. 2018). As stated by Piano et al. (2019), a decline in butterfly species richness was as a result of higher levels of urbanization, which affected the complexity of the vegetation layer and structure that was available in urban patches (Chowdhury et al. 2017). These factors, i.e. isolation and habitat management, could be the reasons for similarity in predacious arthropod communities (homogenization) within fragmented grasslands of settlements with higher levels of urbanization.

Habitat management affects the vegetation structure within urban green spaces, which has been indicated to influence spider assemblages in Argentina (Argañaraz et al. 2018). This was not an aspect that was quantified in this study, but vegetation structure could also influence certain arthropods and thus change predator community assemblages. During this study, the grass layer was taller within the city compared to the rangelands due to lack of grazing or mowing. In all the settlements, the vegetation structure was tallest in fragmented grassland. Thus, local practices of intense management of short-structured ruderal grasslands, could also affect predacious arthropod communities as the vegetation layer is altered resulting in fewer niches. This has also been reported for agricultural areas surrounding these specific IPD and LPD settlements (Botha et al. 2017).

The homogenization of ruderal grasslands of less densely populated areas in this study could be related to the similar extent of transformation of ruderal areas. The transformation in these two settlements was less intensive than that of ruderal grassland within HPD. These sites are less prone to habitat management, isolation, or differences in vegetation structure, which resulted in the similarity of predacious arthropod composition. Similarly, Argañaraz et al. (2018) indicated that spider community composition was similar along an urban gradient, and that their composition in less densely populated areas (suburban and exurban) was more similar than in highly transformed (urban) areas. This is in contrast to the findings of Nagy et al. (2018) who reported no differences in spider communities along an urban gradient. 
In this study, urban grasslands (increased levels of transformation) had lower diversity than the surrounding peri-urban rangelands (less transformed control), which addresses our third objective. These results, therefore, provide evidence for a filtering effect favoring the functional groups that are best adapted to transformed grasslands (Aronson et al. 2016), and indicate a clear loss of species that are typically found in peri-urban rangeland grasslands. The only slight difference in the urban green spaces was that the exogenously disturbed ruderal grasslands had lower abundance of predacious arthropods compared to fragmented grasslands.

This could be ascribed to the lower disturbance intensity and frequency in fragmented grasslands (Gardiner et al. 2013; Van der Walt et al. 2015). A study conducted on the fragmented grasslands at an international airport indicated that spiders were one of the most abundant arthropod groups (Kutschbach-Brohl et al. 2010), which was similar for the fragmented grasslands of this study. Since ruderal grassland, independent of urban settlement, had a higher disturbance intensity, Sattler et al. (2011) suggested that such grasslands might have fewer, but more resilient arthropod species. Rangelands exhibited higher diversity than the ruderal and fragmented grasslands, probably due to less disturbance and fragmentation as well as the larger availability of structural habitat variation provided in more natural areas (Mata et al. 2017, Botha et al. 2018; Koranyi et al. 2021).

Differences in community composition between the rangelands and ruderal and fragmented grasslands are a result of disturbance intensity as well as different management practices (van der Walt et al. 2013), or age, shape, and edge effect of the urban patches (Bolger et al. 2000). Our findings support our third hypothesis that species assemblages change with increasing urbanization since there was a clear difference in species composition associated with fragmented or ruderal grasslands versus peri-urban rangeland grasslands.

Furthermore, a similar trend was indicated in Switzerland by Sattler et al. (2011) as the arthropod community composition was investigated, i.e. arthropod communities had distinct assemblages for urban and periurban rangeland sites. Lowe et al. (2018) also reported that spider communities differed between different urban green spaces investigated in Sydney, Australia.

Community shifts in this study were mostly attributed to spider species, but coccinellid species also contributed to the observed distinct community composition across the three green space types. Delgado de la Flor et al. (2020) indicated that frequent mowing affects bigger spider species more than smaller species since the latter are less sensitive to disturbance at a fine-scale while proportion of impervious surfaces cause distinct spider communities at a landscape scale. These community differences could therefore be due to a variety of factors at various scales, for example, habitat isolation, quality, fragmentation, plant productivity and management frequency or intensity as suggested by Burkman and Gardiner (2014) and Delgado de la Flor et al. (2020).
Adams et al. (2020) reported that urban arthropods are affected by a mixture of fine, local, and landscape-scale mechanisms. Thus vegetation diversity, cover, structure, frequency of mowing at a fine scale (Lowe et al. 2017, 2018; Philpott et al. 2020; Koranyi et al 2021), the mosaic of the urban green spaces within a city, level of urbanization and isolation at a local scale (Delgado de la Flor et al. 2020; Fenoglio et al. 2020; Rocha and Fellowes 2020) and even rainfall (Lowe et al. 2017) at a regional level can influence arthropod abundance, richness and communities such as the ones included in this study. Furthermore, different species react differently to different environmental disturbances and mechanisms (Rocha and Fellowes 2020), thus influencing the patterns and trends we observe.

The general consensus seems to be that urbanization negatively influences arthropod predators compared to rural or peri-urban environments with less effects of urbanization (Fenoglio et al. 2020; Rocha and Fellowes 2020; Koranyi et al. 2021). Peri-urban rangelands and urban environments share species but the communities with these environments differ. Our study agrees with these findings but indicates that the level of disturbance within a city, population density and grassland type could also influence predacious arthropods. As stated by Rocha and Fellowes (2020) urban areas are not less diverse but are simply structured differently.

In conclusion, patch size did not affect overall predacious arthropod diversity. However, coccinellid abundance was influenced by the size of the ruderal urban patches, which might be due to an increased abundance of prey. In more densely populated settlements, a higher abundance and richness of predacious arthropods were found in ruderal and fragmented grasslands within the urban ecosystem, respectively. However, this was significantly lower than the abundance, richness and overall diversity of predacious arthropod species in associated peri-urban rangeland grasslands. Predacious arthropod community composition patterns varied, with fragmented grassland sites being more similar between densely populated settlements, while less densely populated settlements were similar with regards to ruderal grasslands. The community composition of predacious arthropods in rangelands also differed from the urban grassland types, and differences in assemblages between the ruderal and fragmented grasslands were evident.

We acknowledge that predacious arthropod responses to land use are mediated by local factors (Jung et al. 2017), and that the findings of this study are indicative of grassland ecosystems and cities not associated with metropolitan areas. Further research is needed in cities in different biomes (Botha et al. 2016) and metropolitan areas in grassland ecosystems to fully understand the diversity patterns of predacious arthropod groups in urban green space and should attempt to find commonalities in management processes and degrees of isolation for cities with similar predacious arthropod diversity. That would provide a clearer picture regarding arthropod community composition and species assemblages within the urban environment. 
Urban grassland ecosystems have a considerable predacious arthropod diversity, which should inform urban management/conservation. Predacious arthropod assemblages differ considerably between rangelands and urban grasslands, but also between fragmented and ruderal grasslands and these arthropods react differently to levels of urbanization. Thus, urban management and conservation efforts should be focused on the effects of isolated patches, management practices and vegetation structure and keep in mind that despite the lack of assigned function of urban grasslands they are important areas for sustaining diverse and distinct predacious arthropods communities. Increasing connectivity between these diverse urban patches could be an important factor that could contribute not only to the effectiveness of urban corridors, but sustaining and possibly conserving various predacious arthropods. This contributes not only to the health of an ecosystem, but also to its resilience.

\section{ACKNOWLEDGEMENTS}

We thank the Insect Identification Service at the Plant Protection Research Institute's Biosystematics Division, specifically Dr. M.W. Mansell for the identifications of Neuroptera, Dr. R. Stals for the Coccinellidae, and Dr. A. Dippenaar-Schoeman for the Araneae. We also thank the Ditsong National Museum of Natural History in Pretoria, specifically Ms. A. Ndaba, for her assistance and access to the insect collection. Lastly, we want to thank Melanie Schoeman, Anton Botha and Dennis Komape and for their assistance.

\section{REFERENCES}

Adams BJ, Li E, Bahlai CA, Meineke EK, McGlynn TP, Brown BV. 2020. Local and landscape-scale variables shape insect diversity in an urban biodiversity hot spot. Ecol Appl 30: 1-14. DOI: 10.1002/eap.2089.

Alcamo J, Bennett EM. 2003. Ecosystems and Human Well-Being: A Framework for Assessment. Island Press, Washington.

Argañaraz CI, Rubio GD, Gleiser RM. 2018. Spider communities in urban green patches and their relation to local and landscape traits. Biodivers Conserv 27: 981-1009. DOI: 10.1007/s10531-017-1476-8.

Aronson MFJ, Nilon CH, Lepczyk CA, Parker TS, Warren PS, Cilliers SS, Goddard MA, Hahs KA, Herzog C, Katti M, La Sorte FA Williams NSG, Zipperer W. 2016. Hierarchical filters determine community assembly of urban species pools. Ecology 97: 2952-2963. DOI: $10.1002 /$ ecy.1535.

Blair RB. 2001. Birds and butterflies along urban gradients in two ecoregions of the United States: Is urbanization creating a homogeneous fauna? In: Lockwood JL, Mckinney ML (eds). Biotic Homogenization. Kluwer Academic/Plenum, New York. DOI: 10.1007/978-1-4615-1261-5_3.

Blouin D, Pellerin S, Poulin M. 2019. Increase in non-native species richness leads to biotic homogenization in vacant lots of a highly urbanized landscape. Urban Ecosyst 22: 879-892. DOI: 10.1007/s11252-019-00863-9.

Bolger DT, Suarez AV, Crooks KR, Morrison SA, Case TJ. 2000 Arthropods in urban habitat fragments in southern California: Area, age and edge effect. Ecol Appl 10: 1230-1248. DOI: 10.1890/10510761(2000)010[1230:AIUHFI]2.0.CO;2.

Botha M, Siebert SJ, Van den Berg J. 2016. Do arthropod assemblages fit the grassland and savanna biomes of South Africa? S Afr J Sci 112: 1-10. DOI: $10.17159 /$ sajs.2016/20150424.
Botha M, Siebert SJ, Van den Berg J. 2017. Grass abundance maintains positive plant-arthropod diversity relationships in maize fields and margins in South Africa. Agric For Entomol 19: 154-162. DOI: 10.1111/afe.12195.

Botha M, Siebert SJ, Van den Berg J, Ellis S, Greyvenstein B. 2018. Diversity patterns of selected predaceous arthropod groups in maize fields and margins in South African Highveld grassland. Agric For Entomol 20: 461-475. DOI: 10.1111/afe.12277.

Bragg P. 1996-2007. Mantis study group newsletters 1-27 (August 1996October 2007). Available: http://mantodea.myspecies.info/dowloadback-issues-msg-newsletter. [Accessed 18 July 2015.]

Brooks SJ. 1994. A taxonomic review of the common green lacewing genus Chrysoperla (Neuroptera: Chrysopidae). Bull $\mathrm{Br}$ Nat Hist (Entmol) 63: 137-210.

Buchholz S, Hannig K, Möller M, Schirmel J. 2018. Reducing management intensity and isolation as promising tools to enhance ground-dwelling arthropod diversity in urban grasslands. Urban Ecosyst 21: 1139-1149. DOI: 10.1007/s11252-018-0786-2.

Bullock JM, Aronson J, Newton AC, Pywell RF, Rey-Benayas JM. 2011. Restoration of ecosystem services and biodiversity: Conflicts and opportunities. Trends Ecol Evol 26: 541-549. DOI: 10.1016/j.tree.2011.06.011.

Burkman CE, Gardiner MM. 2014. Urban green space composition and landscape context influence natural enemy community composition and function. Biol Control 75: 58-67. DOI: 10.1016/j.biocontrol.2014.02.015.

Buschke FT, Seaman MT. 2011. Functional feeding groups as a taxonomic surrogate for a grassland arthropod assemblage. Afr Invertebr 52: 217-228. DOI: 10.5733/afin.052.0112.

Cardoso P, Barton PS, Birkhofer K, Chichorro F, Deacon C, Fartmann T et al. 2020. Scientists' warning to humanity on insect extinctions. Biol Conserv 242: 1-13. DOI: 10.1016/j.biocon.2020.108426.

Chowdhury S, Hesselberg T, Böhm M, Islam MR, Aich U. 2017. Butterfly diversity in a tropical urban habitat (Lepidoptera: Papilionoidea). Orient Insects 51: 417-430. DOI: 10.1080/00305316.2017.1314230.

Cilliers SS, Bredenkamp GJ. 1999. Ruderal and degraded natural vegetation on vacant lots in the Potchefstroom municipal area, North West province, South Africa. S Afr J Bot 65: 163-173. DOI: 10.1016/S0254-6299(15)30956-X.

Cilliers SS, Williams NS, Barnard FJ. 2008. Patterns of exotic plant invasions in fragmented urban and rural grasslands across continents. Landsc Ecol 23: 1243-1256. DOI: 10.1007/s10980-008-9295-7.

Cilliers SS, Siebert SJ, Du Toit MJ, Davoren E. 2017. Managing urban green spaces for biodiversity conservation: An African perspective. In: Ossola A, Niemela J (eds.). Urban Biodiversity: From Research to Practice. Routledge, Oxford. DOI: 10.9774/gleaf.9781315402581_12.

Clarke KR, Gorley RN. 2006. PRIMER V6: User Manual/Tutorial. PRIMER-E, Plymouth, West Hoe, U.K.

Corcos D, Cerretti P, Caruso V, Mei M, Falco M, Marini L. 2019. Impact of urbanization on predator and parasitoid insects at multiple spatial scales. PLoS ONE 14: 1-15. DOI: 10.1371/journal.pone.0214068.

Dale AG, Frank SD. 2018. Urban plants and climate drive unique arthropod interactions with unpredictable consequences. Curr 29: 27 33. DOI: 10.1016/j.cois.2018.06.001.

Delgado de la Flor YA, Perry KI, Turo KJ, Parker DM, Thompson JL, Gardiner MM. 2020. Local and landscape-scale environmental filters drive the functional diversity and taxonomic composition of spiders across urban greenspaces. J Appl Ecol 57: 1570-1580. DOI: 10.1111/1365-2664.13636.

Dippenaar-Schoeman AS, Jocqué R. 1997. African Spiders: An Identification Manual. ARC-Plant Protection Research Inst., Biosystematics Division, National Collection of Arachnida, Pretoria.

Du Toit MJ, Cilliers SS. 2011. Aspects influencing the selection of representative urbanization measures to quantify urban-rural gradients. Landsc Ecol 26: 169-181. DOI: 10.1007/s10980-010-95604.

Egerer M, Li K, Ong TWY. 2018a. Context matters: Contrasting ladybird beetle responses to urban environments across two US regions. Sustainability 10: 1-17. DOI: 10.3390/su10061829.

Egerer MH, Liere H, Bichier P, Philpott SM. 2018b. Cityscape quality and resource manipulation affect natural enemy biodiversity in and fidelity to urban agroecosystems. Landsc Ecol 33: 985-998. DOI: 10.1007/s10980-018-0645-9. 
Ellis EC, Antill EC, Kreft H. 2012. All is not loss: Plant biodiversity in the Anthropocene. PLoS ONE 7: e0030535. DOI: 10.1371/journal.pone.0030535.

Ellis SM, Steyn HS. 2003. Practical significance (effect sizes) versus or in combination with statistical significance (p-values). Manag Dynamics 12 (4): 51-53.

Evers CR, Wardropper CB, Branoff B, Granek EF, Hirsch SL, Link TE, Olivero-Lora S, Wilson C. 2018. The ecosystem services and biodiversity of novel ecosystems: A literature review. Glob Ecol Conserv 13: 1-12. DOI: 10.1016/j.gecco.2017.e00362.

Faeth SH, Bang C, Saari S. 2011. Urban biodiversity: Patterns and mechanisms. Ann New York Acad Sci 1223 (1): 69-81. DOI: 10.1111/j.1749-6632.2010.05925.x

Fenoglio MS, Rossetti MR, Videla M. 2020. Negative effects of urbanization on terrestrial arthropod communities: A meta-analysis. Glob Ecol Biogeogr 29: 1412-1429. DOI: 10.1111/geb.13107.

Gardiner MM, Burkman CE, Prajzner SP. 2013. The value of urban vacant land to support arthropod biodiversity and ecosystem services. Environ Entomol 42: 1123-1136. DOI: 10.1603/EN12275.

Gibbs H, Hochuli DF. 2002. Habitat fragmentation in an urban environment: large and small fragments support different arthropod assemblages. Biol Conserv 106: 91-100. DOI: 10.1016/S00063207(01)00232-4.

Google Earth. 2015. Google Earth 4.0. Potchefstroom, Vanderbijlpark and Ventersdorp. Satellite data layer. Available: http://www.google.com/earth/index.html. [Accessed 29 July 2015.]

Greyvenstein B, Du Plessis H, Moulin N, Van den Berg J. 2020a Distribution of Galepsus spp. in Southern Africa and life history of Galepsus lenticularis (Mantodea: Tarachodidae). Insects 11: 1-17. DOI: $10.3390 /$ insects11020119.

Greyvenstein B, Siebert SJ, van den Berg J. 2020b. Effect of time of day on efficacy of sweep net sampling of arthropod predators in maize agro-ecosystems in the North West Province, South Africa. Afr Entomol 28(1): 150-163. DOI: 10.4001/003.028.0150.

Hammer $\varnothing$, Harper DAT, Ryan PD. 2001. PAST: Paleontological statistics software package for education and data analysis. Paleontol Electron 4: 1-9.

Honek A, Dixon AFG, Soares AO, Skuhrovec J, Martinkova Z. 2017. Spatial and temporal changes in the abundance and composition of ladybird (Coleoptera: Coccinellidae) communities. Curr Opin Insect Sci 20: 61-67. DOI: 10.1016/j.cois.2017.04.001.

IBM. 2017. SPSS Statistics for Windows, Version 25.0. IBM Corp., Armonk, NY.

Janse Van Rensburg PD, Siebert SJ, Masehela T, Ellis S, Van den Berg J. 2020. Diversity patterns of plants and arthropods in soybean agroecosystems in the Grassland biome of South Africa. Biodiversitas 21: 5559-5570. DOI: $10.13057 /$ biodiv/d211201.

Jones EL, Leather SR. 2012. Invertebrates in urban areas: A review. Eur J Entomol 109: 463-478. DOI: 10.14411/eje.2012.060.

Jung M, Hill SLL, Platts PJ, Marchant R, Siebert SJ, Fournier A, Munyekenye FB, Purvis A, Burgess ND, Newbold T. 2017. Local factors mediate the response of biodiversity to land use on two African mountains. Anim Conserv 20: 370-381. DOI: 10.1111/acv.12327.

Kaltenbach AP. 1996. Unterlagen für eine Monographie der Mantodea des südlichen Afrika: 1. Artenbestand, geographische Verbreitung und Ausbreitungsgrenzen (Insecta: Mantodea). Ann Nat Hist Mus Wien 98: 193-346.

Kaltenbach AP. 1998. Unterlagen für eine Monographie der Mantodea (Insecta) des südlichen Afrika: 2. Bestimmungstabellen für die höheren Taxa, Nachträge zum Artenbestand. Ann Nat Hist Mus Wien. 100: 19-59. [Afrikaan]

Kremen C, Merenlender AM. 2018. Landscapes that work for biodiversity and people. Science 362: 1-9. DOI: 10.1126/science.aau6020.

Koranyi D, Szigeti V, Mezöfi L, Kondorosy E, Markó V. 2021. Urbanization alters the abundance and composition of predator communities and leads to aphid outbreaks on urban trees. Urban Ecosyst 24: 571-586. DOI: 10.1007/s1 1252-020-01061.

Kozlov MV, Lanta V, Zverev V, Rainio K, Kunavin MA, Zvereva EL. 2017. Decreased losses of woody plant foliage to insects in large urban areas are explained by bird predation. Glob Change Biol 23: 4354-4364. DOI: $10.1111 / \mathrm{gcb} .13692$

Kutschbach-Brohl L, Washburn BE, Berhardt GE, Chipman RB, Francoeur LC. 2010. Arthropods of a semi-natural grassland in an urban environment: The John F. Kennedy International Airport, New
York. J Insect Conserv 14: 347-358. DOI: 10.1007/s10841-010-92648.

Lowe EC, Wilder SM, Hochuli DF. 2017. Life history of an urban-tolerant spider shows resilience to anthropogenic habitat disturbance. J Urban Ecol 3: 1-10. DOI: 10.1093/jue/jux004.

Lowe EC, Threlfall CG, Wilder SM, Hochuli DF. 2018. Environmental drivers of spider community composition at multiple scales along an urban gradient. Biodivers Conserv 27: 829-852. DOI: 10.1007/s10531-017-1466-x.

Mace GM, Norris K, Fitter AH. 2012. Biodiversity and ecosystem services: A multilayered relationship. Trends Ecol Evol 27: 19-26. DOI: $10.1016 /$ j.tree.2011.08.006.

Magura T, Lovei GL, Tothmeresz B. 2010. Does urbanization decrease diversity in ground beetle (Carabidae) assemblages? Glob Ecol Biogeogr 19: 16-26. DOI: 10.1111/j.1466-8238.2009.00499.x.

Mansell MW. 1997. The antlions of Southern Africa (Neuroptera: Myrmeleontidae): Genus Palparellus Navás, including extralimital species. Afr Entomol 4: 239-267. DOI: 10520/AJA10213589 208.

Marques A, Martins IS, Kastner T et al. 2019. Increasing impacts of land use on biodiversity and carbon sequestration driven by population and economic growth. Nat Ecol Evol 3: 628-637. DOI: 10.1038/s41559019-0824-3.

Mata L, Threlfall CG, Williams NSG, Hahs AK, Malipatil M, Stork NE, Livesley SJ. 2017. Conserving herbivorous and predatory insects in urban green spaces. Sci Rep 7: 1-12. DOI: 10.1038/srep40970.

McIntyre NE, Rango J, Fagan WF, Faeth SH. 2001. Ground arthropod community structure in a heterogeneous urban environment. Landsc Urban Plan 52: 257-274. DOI: 10.1016/S0169-2046(00)00122-5.

McKinney ML. 2008. Effects of urbanization on species richness: A review of plants and animals. Urban Ecosys 11: 161-176. DOI: 10.1007/s11252-007-0045-4.

McMahon SM, Diez JM. 2007. Scales of association: Hierarchical linear models and the measurement of ecological systems. Ecol Lett 10: 437-452. DOI: $10.1111 / j .1461-0248.2007 .01036 . x$.

Nagy DD, Magura T, Horváth R, Debnár Z, Tóthmérész B. 2018. Arthropod assemblages and functional responses along an urbanization gradient: A trait-based multi-taxa approach. Urban For Urban Green 30: 157-168. DOI: 10.1016/j.ufug.2018.01.002.

New TR. 2018. Promoting and developing insect conservation in Australia's urban environments. Austral Entomol 57: 182-19. DOI: 10.1111/aen.12332

Peng MH, Hung YC, Liu KL et al. 2020. Landscape configuration and habitat complexity shape arthropod assemblage in urban parks. Sci Rep 10: 1-12. DOI: 10.1038/s41598-020-73121-0.

Philpott SM, Bichier P. 2017. Local and landscape drivers of predation services in urban gardens. Ecol Appl 27: 966-976. DOI: 10.1002/eap.1500

Philpott SM, Lucatero A, Bichier P, Egerer MH, Jha S, Lin B, Liere H. 2020. Natural enemy-herbivore networks along local management and landscape gradients in urban agroecosystems. Ecol Appl 30: 1-12. DOI: $10.1002 /$ eap. 2201

Piano E, Souffreau C, Merckx T, Baardsen LF, Backeljau T, Bonte D, Brans KI, Cours M et al. 2019. Urbanization drives cross-taxon declines in abundance and diversity at multiple spatial scales. Glob Change Biol 26:1-16. DOI: $10.1111 / \mathrm{gcb} .14934$.

Pryke JS, Samways MJ. 2009. Recovery of invertebrate diversity in a rehabilitated city landscape mosaic in the heart of a biodiversity hotspot. Landsc Urban Plan 93: 54-62. DOI: 10.1016/j.landurbplan.2009.06.003.

Rocha EA, Fellowes MDE. 2020. Urbanisation alters ecological interactions: Ant mutualists increase and specialist insect predators decrease on an urban gradient. Sci Rep 10: 1-8. DOI: 10.1038/s41598-020-62422-z.

Rocha EA, Fellowes MDE. 2018. Does urbanization explain differences in interactions between an insect herbivore and its natural enemies and mutualists? Urban Ecosyst 21: 405-417. DOI: 10.1007/s11252-0170727-5.

Sanchez-Bayo F, Wyckhuys KAG. 2019. Worldwide decline of the entomofauna: A review of its drivers. Biol Conserv 232: 8-27. DOI: 10.1016/j.biocon.2019.01.020

Sattler T, Obrist MJ, Deulli P, Moretti M. 2011. Urban arthropod communities: Added value or just a blend of surrounding biodiversity? Landsc Urban Plan 103: 347-361. DOI: 10.1016/j.landurbplan.2011.08.008.

Seago A, Giorgi JS, Li J, Slipinski A. 2011. Phylogeny, classification and evolution of ladybird beetles (Coleoptera: Coccinellidae) based on 
simultaneous analysis of molecular and morphological data. Mol Phylogenet Evol 60:137-51. DOI: 10.1186/s12862-017-1002-3.

Soga M, Kanno N, Yamaura Y, Koike S. 2013. Patch size determines the strength of edge effects on carabid beetle assemblages in urban remnant forests. J Insect Conserv 17: 421-428. DOI: 10.1007/s10841012-9524-x.

Threlfall CG, Walker K, Williams NS, Hahs AK, Mata L, Stork N, Livesley SJ. 2015. The conservation value of urban green space habitats for Australian native bee communities. Biol Conserv 187: 240-248. DOI: 10.1016/j.biocon.2015.05.003

Turrini T, Sanders D, Knop E. 2016. Effects of urbanization on direct and indirect interactions in a tri-trophic system. Ecol Appl 26: 664-675. DOI: $10.1890 / 14-1787$.

Van der Walt L, Cilliers SS, Kellner K, du Toit MJ, Tongway D. 2013. To what extent does urbanisation affect fragmented grassland functioning? J Environ Manag 151: 517-530. DOI: 10.1016/j.jenvman.2014.11.034.

Van der Walt L, Cilliers SS, du Toit MJ, Kellner K. 2015. Conservation of fragmented grasslands as part of the urban green infrastructure: How important are species diversity, functional diversity and landscape functionality? Urban Ecosyst 18: 87-113. DOI: 10.1007/s11252-0140393-9.

Venter AD, Vakkari V, Beukes JP, Van Zyl PG, Laakso H, Mabaso D, Tiitta P, Josipovic M, Kulmala M, Pienaar J. 2012. An air quality assessment in the industrialised western Bushveld Igneous Complex, South Africa. S Afr J Sci 108: 1-10. DOI: 10.4102/sajs.v108i9/10.1059.

Wani AM, Sahoo G. 2021. Forest ecosystem services and biodiversity. In: Shit PK, Pourghasemi HR, Das P, Bhunia GS (eds). Spatial Modeling in Forest Resources Management. Springer, Switzerland.

Wagner LS, Fenoglio MS, Salvo A. 2017. Alien species numerically dominate natural enemy communities in urban habitats: A preliminary study. J Entomol Res Soc 19: 31-42.

Whitmore C, Crouch TE, Slotow RH. 2002. Conservation of biodiversity in urban environments: Invertebrates on structurally enhanced road islands. Afr Entomol 10: 113-126. 


\section{SUPPLEMENTARY MATERIALS}

Table S1. Total predacious arthropod species abundances recorded for both sampling events in the urban ecosystems. Species recorded from a single settlement is indicated with * and from only one land-use type with \#.

\begin{tabular}{|c|c|c|c|c|c|c|c|c|c|}
\hline \multirow{2}{*}{ Order } & \multirow{2}{*}{ Family } & \multirow{2}{*}{ Species } & \multirow{2}{*}{$\begin{array}{l}\text { Peri-urban } \\
\text { rangelands }\end{array}$} & \multicolumn{3}{|c|}{ Ruderal grassland } & \multicolumn{3}{|c|}{ Fragmented grassland } \\
\hline & & & & HPD & IPD & LPD & HPD & IPD & LPD \\
\hline \multirow[t]{39}{*}{ Araneae } & Linyphiidae & Agyneta habra*\# & 2 & - & - & - & - & - & - \\
\hline & Araneidae & Araneus apricus $* \#$ & 1 & - & - & - & - & - & - \\
\hline & Araneidae & Argiope australis*\# & 1 & - & - & - & - & - & - \\
\hline & Eutichuridae & Cheiracanthium sp. & 1 & 1 & 1 & 1 & 2 & - & - \\
\hline & Theridiidae & Enoplognatha molesta*\# & 13 & - & - & - & - & - & - \\
\hline & Theridiidae & Enoplognatha sp. & 12 & - & 3 & 2 & - & - & 3 \\
\hline & Salticidae & Festucula lawrencei & 2 & 15 & 4 & 1 & 27 & 21 & - \\
\hline & Salticidae & Heliophanus debilis*\# & 3 & - & - & - & - & - & - \\
\hline & Salticidae & Heliophanus sp. *\# & 1 & - & - & - & - & - & - \\
\hline & Araneidae & Hypsosinga lithyphantoides*\# & 1 & - & - & - & - & - & - \\
\hline & Araneidae & Hypsosinga sp. & 56 & 1 & 2 & 4 & 5 & 2 & 5 \\
\hline & Araneidae & Larinia bifida*\# & 19 & - & - & - & - & - & - \\
\hline & Araneidae & Larinia natalensis & 10 & - & - & - & 2 & - & 4 \\
\hline & Theridiidae & Latrodectus renivulvatus & 4 & - & - & - & 3 & - & 1 \\
\hline & Thomisidae & Misumenops rubrodecoratus & 190 & 11 & 33 & 14 & 15 & 8 & 49 \\
\hline & Thomisidae & Monaeses paradoxus & 10 & 8 & 5 & 3 & 12 & 3 & - \\
\hline & Thomisidae & Monaeses pustulosus & 39 & - & 4 & - & 7 & 3 & 1 \\
\hline & Araneidae & Nemoscolus sp. & 1 & - & 1 & - & - & 4 & 1 \\
\hline & Araneidae & Neoscona moreli & 1 & - & - & - & - & - & - \\
\hline & Araneidae & Neoscona subfusca & 10 & 3 & - & 1 & - & 3 & - \\
\hline & Oxyopidae & Oxyopes hoggi*\# & - & - & 1 & - & - & - & - \\
\hline & Oxyopidae & Oxyopes longispinosus & 4 & - & - & - & - & - & 2 \\
\hline & Oxyopidae & Oxyopes schenkeli & 11 & - & - & - & 1 & - & - \\
\hline & Araneidae & Pararaneus sp. *\# & - & - & - & - & - & - & 2 \\
\hline & Lycosidae & Pardosa crassipalpis*\# & 1 & - & - & - & - & - & - \\
\hline & Salticidae & Pellenes bulawayoensis & 16 & - & - & - & - & - & 1 \\
\hline & Oxyopidae & Peucetia striata*\# & - & 2 & 1 & - & 1 & - & - \\
\hline & Philodromidae & Philodromus sp. & 8 & - & - & - & - & - & - \\
\hline & Araneidae & Pycnacantha tribulus*\# & 1 & - & - & - & - & - & - \\
\hline & Thomisidae & Runcinia affinis*\# & 14 & - & - & - & - & - & - \\
\hline & Thomisidae & Runcinia erythrina*\# & 1 & - & - & - & - & - & - \\
\hline & Thomisidae & Runcinia flavida & 58 & 27 & 21 & 14 & 44 & 22 & 23 \\
\hline & Thomisidae & Stiphropus bisigillatus & 3 & - & - & - & - & - & 1 \\
\hline & Philodromidae & Thanatus atlanticus & 5 & - & - & 2 & 3 & 2 & 2 \\
\hline & Theridiidae & Theridion pictum & 2 & 7 & 4 & - & 8 & 4 & - \\
\hline & Salticidae & Thyene semiargentea & 2 & 1 & - & - & 2 & 1 & 1 \\
\hline & Salticidae & Thyene thyenioides & 5 & 1 & 1 & 3 & 1 & 2 & - \\
\hline & Salticidae & Thyenula sp. & 11 & 3 & 4 & 2 & 10 & 5 & - \\
\hline & Philodromidae & Tibellus hollidayi & 45 & 15 & 30 & 12 & 119 & 81 & 45 \\
\hline \multirow{7}{*}{ Coleoptera } & Coccinellidae & Buleae anceps & 46 & 11 & 9 & 7 & 12 & 11 & 7 \\
\hline & Coccinellidae & Cheilomenes lunata & 192 & 80 & 17 & 39 & 18 & 9 & 6 \\
\hline & Coccinellidae & Exochomus flavipes & 71 & 23 & 12 & 1 & 1 & 3 & - \\
\hline & Coccinellidae & Harmonia axyridis & 28 & 3 & - & 2 & - & - & - \\
\hline & Coccinellidae & Hippodamia variegata & 51 & 84 & 6 & 6 & - & - & - \\
\hline & Coccinellidae & Lioadalia flaromaculata & 20 & 17 & - & 3 & 9 & - & 1 \\
\hline & Coccinellidae & Micraspis comma & 9 & 2 & - & 2 & - & - & - \\
\hline \multirow{8}{*}{ Mantodea } & Mantidae & Compsothespis sp. & 1 & - & - & - & 1 & - & 1 \\
\hline & Mantidae & Entella sp. & 1 & 2 & - & - & - & - & - \\
\hline & Tarachodidae & Episcopomantis sp. & 23 & - & - & - & 13 & 9 & - \\
\hline & Tarachodidae & Galepsus sp. & 41 & 17 & 11 & - & - & 1 & - \\
\hline & Galinthiadidae & Harpagomantis sp. & - & 3 & - & - & - & - & 1 \\
\hline & Empusidae & Hemiempusa sp. *\# & - & - & - & - & - & - & - \\
\hline & Tarachodidae & Pyrgomantis sp. & 10 & - & - & - & 1 & - & - \\
\hline & Mantidae & Tenodera sp. & 5 & - & 1 & 2 & - & - & 11 \\
\hline \multirow[t]{2}{*}{ Neuroptera } & Chrysopidae & Chrysoperla congrua & 198 & 6 & 3 & 6 & 2 & 3 & 6 \\
\hline & Chrysopidae & Italocchrysa similis*\# & 34 & - & - & - & - & - & - \\
\hline
\end{tabular}


Table S2. Effect sizes of Hierarchical Linear Modelling (HLM) analysis for comparisons between urban settlements in terms of mean predator diversity index values.

\begin{tabular}{lcccc}
\hline \multicolumn{1}{c}{ Green spaces } & Urban settlement & Species richness & Abundance & Shannon-Wiener index \\
\hline \multirow{2}{*}{ Ruderal } & HPD X IPD & $0.684^{*}$ & $1.190^{* *}$ & 0.312 \\
& HPD X LPD & $0.992^{* *}$ & $1.521^{* *}$ & $0.513^{*}$ \\
\multirow{2}{*}{ Fragmented } & IPD X LPD & 0.308 & 0.331 & 0.201 \\
grassland & HPD X IPD & $1.049^{* *}$ & $0.987^{* *}$ & $0.804^{* *}$ \\
& HPD X LPD & $1.077^{* *}$ & $1.173^{* *}$ & $0.804^{* *}$ \\
& IPD X LPD & 0.028 & 0.186 & 0 \\
\hline
\end{tabular}

Note: Significance codes: ${ }^{* *}$ large effect at $\mathrm{d} \geq 0.8 ; *$ medium effect at $\mathrm{d} \geq 0.5$. HPD: Vanderbijlpark; IPD: Potchefstroom; LPD: Ventersdorp.

Table S3. Effect sizes of Hierarchical Linear Modelling (HLM) analysis for comparisons between tree green space types in terms of mean predator diversity index values.

\begin{tabular}{lccc}
\hline \multicolumn{1}{c}{ Effect sizes } & Species richness & Abundance & Shannon-Wiener index \\
\hline Ruderal X Fragmented grassland & 0.169 & 0.06 & 0.003 \\
Ruderal X Rangeland grassland & $1.347^{* *}$ & $1.18^{* *}$ & $0.825^{* *}$ \\
Fragmented X Rangeland grassland & $1.178^{* *}$ & $1.12^{* *}$ & $0.828^{* *}$ \\
\hline
\end{tabular}

Note: Significance codes: $* *$ large effect at $\mathrm{d} \geq 0.8 ; *$ medium effect at $\mathrm{d} \geq 0.5$

Table S4. Similarity Percentage (SIMPER) analyses between the three settlements. The results indicate the overall dissimilarity percentage, the dissimilarity between each comparison and the contribution made by the five main species. Urban settlements are HPD: Vanderbijlpark; IPD: Potchefstroom; LPD: Ventersdorp

\begin{tabular}{lccc}
\hline & HPD $\times$ IPD & HPD $\times$ LPD & IPD $\times$ LPD \\
\hline Dissimilarity(\%) & $74.47 \%$ & $79.76 \%$ & $79.06 \%$ \\
Taxon 1 & Tibellus hollidayi & Tibellus hollidayi & Tibellus hollidayi \\
(\% Contributed) & $20.7 \%$ & $17.97 \%$ & $20.29 \%$ \\
Taxon 2 & Cheilomenes lunata & Cheilomenes lunata & Misumenops rubrodecoratus \\
(\% Contributed) & $13.02 \%$ & $14.95 \%$ & $13.59 \%$ \\
Taxon 3 & Runcinia flavida & Runcinia flavida & Cheilomenes lunata \\
\% Contributed) & $7.94 \%$ & $9.11 \%$ & $10.76 \%$ \\
Taxon 4 & Hippodamia variegata & Misumenops rubrodecoratus & Runcinia flavida \\
\% Contributed) & $7.21 \%$ & $7.37 \%$ & $9.99 \%$ \\
Taxon 5 & Misumenops rubrodecoratus & Hippodamia variegata & Festucula lawrencei \\
\hline
\end{tabular}

Table S5. Similarity Percentage (SIMPER) analyses between the three settlements. The results indicate the overall dissimilarity percentage, the dissimilarity between each comparison (green spaces) and the contribution made by the five main species.

\begin{tabular}{lccc}
\hline & Fragmented x Peri-urban rangeland & Fragmented x Ruderal & Ruderal x Peri-urban rangeland \\
\hline Dissimilarity (\%) & $86.93 \%$ & $79.26 \%$ & $84.94 \%$ \\
Taxon 1 & Tibellus hollidayi & Tibellus hollidayi & Cheilomenes lunata \\
(\% Contributed) & $13.25 \%$ & $21.42 \%$ & $11.69 \%$ \\
Taxon 2 & Chrysoperla congrua & Cheilomenes lunata & Chrysoperla congrua \\
(\% Contributed) & $13.02 \%$ & $12.80 \%$ & $11.46 \%$ \\
Taxon 3 & Misumenops rubrodecoratus & Misumenops rubrodecoratus & Misumenops rubrodecoratus \\
(\% Contributed) & $9.87 \%$ & $9.33 \%$ & $10.19 \%$ \\
Taxon 4 & Cheilomenes lunata & Runcinia flavida & Galepsus sp. \\
(\% Contributed) & $8.29 \%$ & $8.77 \%$ & $6.35 \%$ \\
Taxon 5 & Runcinia flavida & Festucula lawrencei & Hippodamia variegate \\
(\% Contributed) & $5.79 \%$ & $5.39 \%$ & $5.78 \%$ \\
\hline
\end{tabular}


A

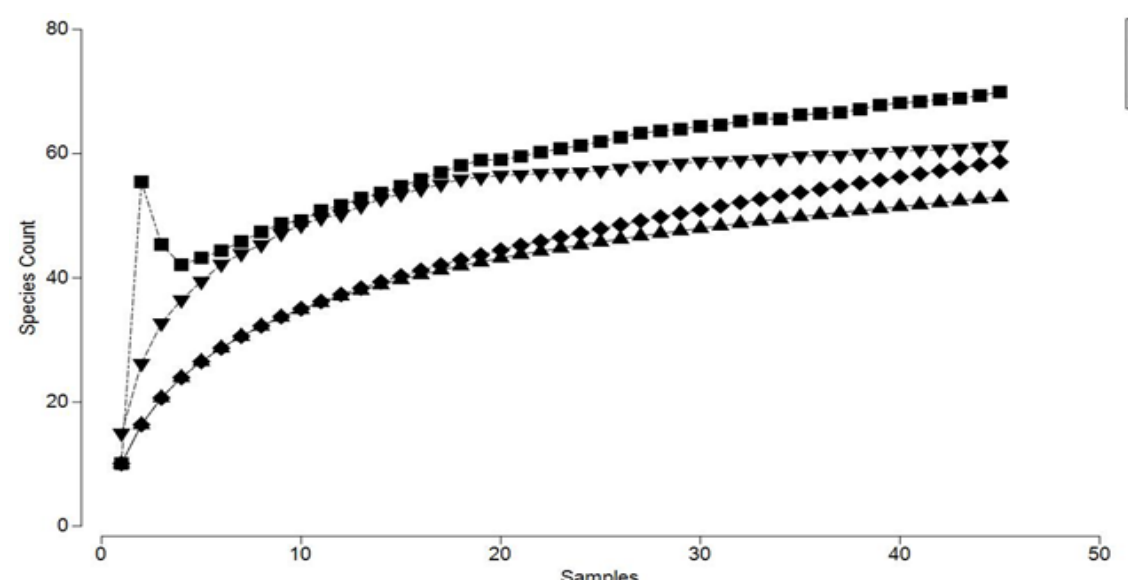

B

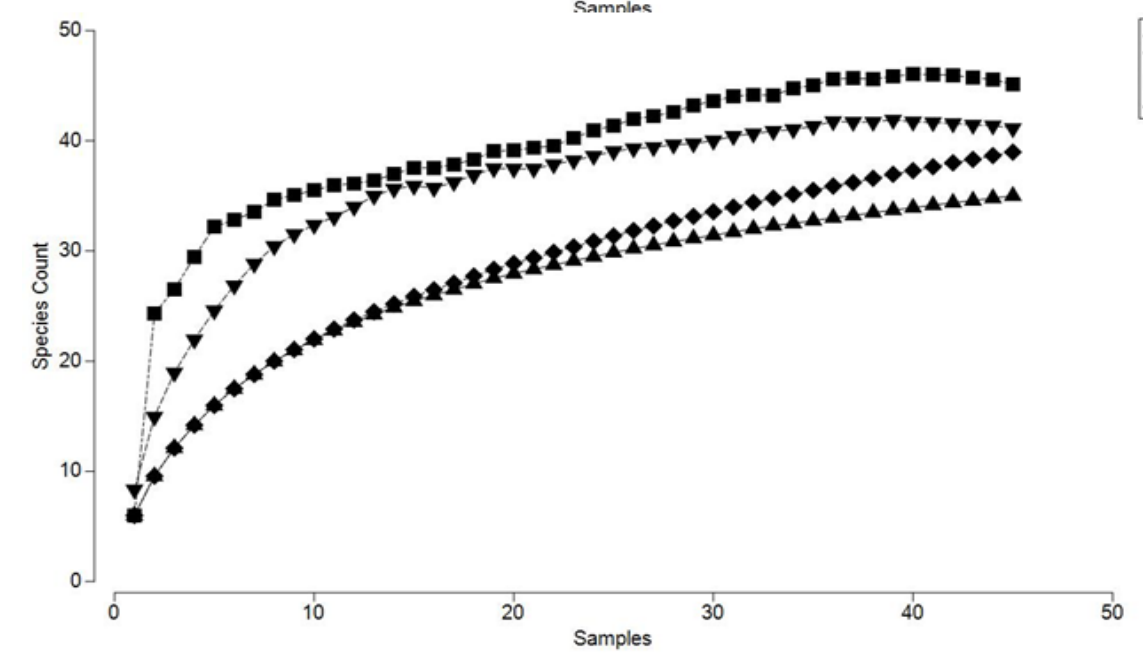

C

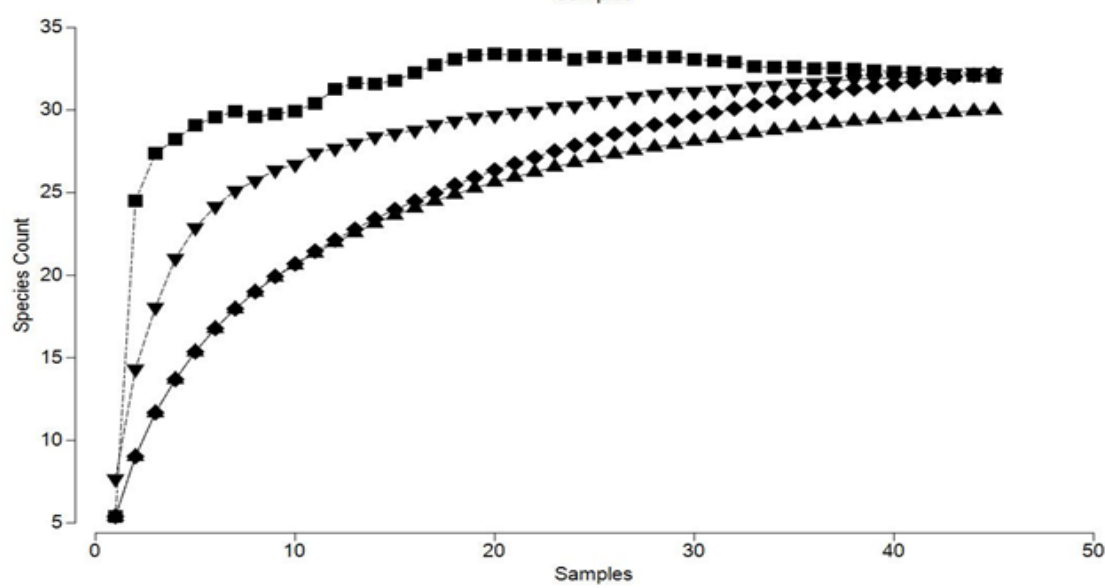

Figure S1. Sample based rarefraction curves for each green space type. A. Rangelands, B. Fragmented grassland, C. Ruderal grassland samples. 